ks. Tomasz Dariusz Mames, Blaski i cienie wychowania do ekumenizmu - refleksje z perspektywy mariawity, [w:] o co chodzi w ekumenizmie? Czym jest dialog? Podstawowe idee Vaticanum II pót wieku później, red. Marek Kita, Kraków 2015, s. 59-85. DOI: http://dx.doi.org/10.15633/9788374384551.06

\title{
Blaski i cienie wychowania do ekumenizmu - refleksje z perspektywy mariawity
}

Truizmem jest stwierdzenie, że istnieje podział pomiędzy uczniami Jezusa Chrystusa. Dotyczy on zarówno kwestii doktrynalnych, jak i organizacyjnych. Na przestrzeni prawie dwóch tysięcy lat istnienia chrześcijaństwa próbowano różnymi środkami i na różne sposoby przywrócić jedność w Kościele. Żadne z rozwiązań nie zażegnały sporów, a wręcz przeciwnie, niektóre z nich tylko pogłębiły podziały. Niemniej jednak poszczególne Kościoły partykularne wypracowały pewnego rodzaju modele komunii (jedności) między sobą. Można więc wyróżnić unię organiczną, jedność korporacyjną, federacyjną, wspólnotę kościelną opartą na konkordii, wspólnotę koncyliarną, jedność w pojednanej różnorodności, wspólnotę z papieżem, jedność Kościoła jako „koinonię” czy jedność przez wielość ${ }^{1}$.

Owe modele stają się punktem odniesienia dla wychowania do ekumenizmu. Na wstępie jednak należałoby wyjaśnić, czym jest wychowanie i czym jest ekumenizm. W ujęciu pedagogicznym wychowanie należy do dziedziny edukacji, czyli ogółu „oddziaływań służących formowaniu się (zmienianiu, rozwijaniu)

1 Szerzej pisze o tym Karol Karski w swej pracy Od Edynburga do Porto Alegre. Sto lat dążé ekumenicznych, Warszawa 2007, s. 32-41. 
zdolności życiowych człowieka"2. Jest więc ono świadomym i celowym działaniem pedagogicznym zmierzającym do „osiągnięcia względnie stałych skutków (zmian rozwojowych) w osobowości wychowanka"3. Szczególnym rodzajem wychowania jest autoformacja, w której jednostka staje się wychowawcą samego siebie. Ekumenizm jako fenomen staje się postawą zaangażowania jednostki czy określonych społeczności na rzecz zjednoczenia chrześcijan. Wydaje się, że najbardziej trafną definicją ekumenizmu jest ta, którą zaproponował luterański arcybiskup Uppsali Nathan Söderbolm. Zdaniem hierarchy ekumenizm to „wyrażenie postawy duchowej, świadczące o głębokiej wiedzy z zakresu fundamentalnej jedności Kościołów chrześcijańskich" ${ }^{4}$. Według niego istnieje podstawowa jedność Kościoła, który posiada wspólne zadanie w świecie.

Jest charakterystyczne, że wychowanie do ekumenizmu stanowi element doktryny Kościoła Starokatolickiego Mariawitów. Kościół mariawitów swych zasad wiary nie narzuca innym chrześcijanom. Teolodzy mariawiccy są zdania, iż przyjdzie czas, gdy wszyscy chrześcijanie poznają Boga takiego, jakim jest w rzeczywistości, nie zaś pod zasłoną (1 Kor 13, 12). Tych, którzy nie podzielają starokatolickiej nauki, nie uważa się za heretyków, lecz za współbraci w Chrystusie, do którego wszyscy dążymy, aczkolwiek innymi drogami ${ }^{5}$. Synod Kościoła Starokato-

2 K. Rubacha, Edukacja jako przedmiot pedagogiki i jej subdyscyplin, [w:] Pedagogika. Podręcznik akademicki, red. Z. Kwieciński, B. Śliwerski, Warszawa 2006, s. 25.

3 K. Rubacha, Edukacja jako przedmiot pedagogiki i jej subdyscyplin, dz. cyt., s. 26.

4 K. Karski, Od Edynburga do Porto Alegre..., dz. cyt., s. 25-26.

5 Idea religijna Marjawickiego Kościoła, „Głos Prawdy” (1936) nr 51, s. 496. Szerzej temat eklezjologii Kościoła Starokatolickiego Mariawitów przedstawiłem w koreferacie wygłoszonym podczas sympozjum „Pojednanie jako zadanie Kościołów w Europie. Pryncypia eklezjologiczne w świetle Nowego Testamentu" (Chrześcijańska Akademia Teologiczna w Warszawie, 13 maja 2014), tekst w druku. Zob. M. M. Sitek, Pojęcie Kościoła według nauki Błogosławionej Marii Franciszki, „Mariawita” (2012) nr 4-6, s. 30-32; M. Daniel [T. D. Mames], Krótki zarys eklezjologii Kościoła Starokatolickiego Mariawitów, „Mariawita” (2012) 


\section{lickiego Mariawitów z 1935 roku ujął tę kwestię w następujący sposób:}

różnorodność przekonań religijnych w oczach Chrystusa Pana nie jest czymś ujemnym, ale raczej pożądaniem, gdyż daje możność wszystkim duchom, stosownie do ich rozwoju i zdolności pojmowania Boga, znaleźć dla siebie odpowiedni wykładnik w religii. Prawdziwa jedność, o którą modlił się Chrystus Pan, niekoniecznie musi być jednostajnością, jak mniemają przedstawiciele niektórych Kościołów, ale właśnie zjednoczeniem różnic (zob. J 17, 21) $)^{6}$.

Niemniej jednak „nie godzi się podzielać błędnych przekonań bliźniego, ale nie wolno nam potępiać go za nie"7.

Orzeczenie synodalne doskonale wpisuje się w słowa św. Marii Franciszki Kozłowskiej, traktujące o problemie jedności chrześcijan: ,jak nadzieja na przyjście Messyasza-Króla zawiodła Żydów, wiara w dogmaty rozdzieliła narody, tak miłość zjednoczy wszystkich [...]"8.

Głównym fundamentem zjednoczenia, mówiła Mateczka, powinna być wiara i cześć dla Przenajświętszego Sakramentu Ołtarza [...]. Każdy Kościół niech też zachowuje swoje zwyczaje, modły i nabożeństwa i niech drugiemu swoich praktyk religijnych nie narzuca. We wszystkiem niech będzie miłość, w rzeczach niekoniecznych do zbawienia - wolność, a w koniecznych jedność9.

nr 10-12, s. 6-7; tenże, Glosy na marginesie tekstu o eklezjologii Kościoła Starokatolickiego Mariawitów, „Mariawita” (2013) nr 1-3, s. 26.

6 Stosunek Staro-Katolickiego Kościoła Maryawitów do innych wyznań(Stanowisko Kościoła urzędownie określone na Synodzie), „Głos Prawdy” (1935) nr 9, s. 69. Chrześcijanie mają zachować jedność na wzór jedności Boga Ojca i Syna Bożego, Jezusa Chrystusa. Niemniej jednak Bóg Ojciec, stanowiąc jedno z Synem Bożym, nie jest Nim, ani Syn nie jest Ojcem.

7 J. M. M. Kowalski, List Pasterski z 31 grudnia 1909 r., Łódź 1909, s. 20. Por. Rzym 14, 4.

8 M. F. Kozłowska, Dzieło Wielkiego Miłosierdzia, Płock 1927, s. 68.

9 M. F. Kozłowska, Dzieło Wielkiego Miłosierdzia, dz. cyt., s. 287. 
Należy więc zauważyć, iż skoro miłość jest warunkiem sine qua non zjednoczenia uczniów Chrystusa, będąc jednoczenie principium eklezjologicznym, wychowanie do ekumenizmu jest wychowaniem do miłości.

Nie sposób nie przywołać w tym miejscu perykopy z 12 rozdziału Ewangelii według św. Marka. Gdy zapytano Chrystusa, które z przykazań jest najprzedniejsze, Jezus odpowiedział, że

najprzedniejsze ze wszystkich przykazań jest: Słuchaj Izraelu! Pan, Bóg twój, Bóg jeden jest; i będziesz miłował Pana Boga twego z całego serca twego i z całej duszy twojej, i ze wszystkiego umysłu twego, i ze wszystkiej siły twojej: toć jest pierwsze przykazanie. A wtóre jest temu podobne: Będziesz miłował bliźniego twego, jako samego siebie. Większego przykazania nad to dwoje nie ma (Mk 12, 29-32) ${ }^{10}$.

Co to oznacza? Nie mogę miłować bliźniego, nie kochając siebie. Miłość samego siebie to nie narcyzm czy egoizm, to stawanie w prawdzie przed Bogiem i samym sobą. Człowiek miłujący siebie widzi doskonale, jakie posiada cnoty, ale też i jakie ma wady (por. J 8, 23). Dzięki temu może pracować nad sobą i rozwijać w sobie to wszystko, co jest dobre, jednocześnie wyniszczając to, co jest złe. Może się samowychowywać, autoformować się. Miłować bliźniego, znaczy towarzyszyć mu w jego trudach i radościach. Święty Paweł naucza: „radujcie się z tymi, którzy się weselą; płaczcie z tymi, którzy płaczą" (Rz 12, 15). Czasem wystarczy, że jesteśmy przy drugim człowieku. Wreszcie, miłować Boga, znaczy oddać się całkowicie swojemu Stwórcy, Jemu zaufać i umiłować Jego wolę, która ma się nad nami, $\mathrm{w}$ nas i przez nas pełnić11. A zatem w odniesieniu do pedagogii Kościoła Starokatolickiego Mariawitów należałoby mówić o wychowaniu i jednocześnie samowychowaniu w miłości do ekumenizmu. Wynika to także i z innej tezy zawartej w objawieniach

10 Przekład mariawicki.

${ }_{11}$ Por. Notatki z Objawień Mateczki z roku jubileuszowego 1918-go, [w:] św. M. F. Kozłowska, Dzieło Wielkiego Miłosierdzia, dz. cyt., s. 80. 
św. Marii Franciszki Kozłowskiej. Założycielka miała objawione, iż Chrystus „odjął wszystkim Kapłanom moc nad duszami i sercami ludzkiemi [...]. Pozostawił Pan Jezus Kapłanom tylko sprawowanie Sakramentów Św. i zewnętrzny zarząd w Kościele do czasu"12. Nie oznacza to jednak, iż duchowny jest wyłączony z procesu wychowawczego. Jego zadaniem jest raczej dawanie przykładu, pobudzanie do aktywności ekumenicznej i wyjaśnianie, aniżeli np. agitacja na rzecz zaniechania współpracy z ludźmi o innej przynależności konfesyjnej. Naczelnym powołaniem kapłana mariawity pozostaje zawsze szerzenie czci Przenajświętszego Sakramentu i w tej perspektywie należałoby rozpatrywać wychowanie do ekumenizmu.

Wychowanie do ekumenizmu jest zawsze wychowaniem/ autoformacją do stawania się członkiem własnego Kościoła. Z rozmysłem użyłem słowa „stawanie się”, gdyż procesy wychowawcze czy też autoformacyjne mają charakter ustawiczny. Ich dynamika determinowana jest kondycją jednostki świadomej swej odpowiedzialności za świat. Z objawień św. Marii Franciszki wnioskować można, że od każdego z ludzi zależy, czy święty będzie podążał drogą Bożych przykazań, czy też będzie się oddalał od swojego Stwórcy, idąc ku zatraceniu ${ }^{13}$. A ponieważ fundamentem egzystencji Kościoła Starokatolickiego Mariawitów jest przede wszystkim szerzenie czci eucharystycznej oraz naśladowanie życia Najświętszej Maryi Panny, wychowanie to winno się opierać na tych dwóch elementach konstytuujących mariawicką tożsamość wyznaniową. Wychowanie do ekumenizmu musi być zawsze procesem wtórnym w stosunku do formacji tożsamościowej.

Wychowanie do ekumenizmu w mniejszości wyznaniowej, a w tym kontekście mniejszości mariawickiej, może być rozpatrywane również w jeszcze dwóch innych wymiarach: uczest-

12 Por. Notatki z Objawień Mateczki z roku jubileuszowego 1918-go, dz. cyt., s. 78.

${ }^{13}$ Por. Początek Zawiązku Zgromadzenia Kapłanów, [w:] św. M. F. Kozłowska, Dzieło Wielkiego Miłosierdzia, dz. cyt., s. 5, 32; Notatki z roku jubileuszowego 1918-go, [w:] św. M. F. Kozłowska, Dzieło Wielkiego Miłosierdzia, dz. cyt., s. 77, 80. 
nictwa w procesie kształcenia na poszczególnych szczeblach szkolnictwa oraz kreowania dyskursu na temat własnej historii i doktryny. Wymiar uczestnictwa, z racji przesunięcia sfery sakralnej w przestrzeń edukacyjną (a zarazem publiczną), implikuje heterogenizację sfery religijnej szkoły. Wyznanie mniejszościowe, a w tym także i mariawickie, jako element różnicujący uczniów i dezintegrujący plan wychowawczy szkoły odnośnie do partycypowania w wartościach religijnych wymusza na pedagogach, duchowieństwu oraz rodzicach negocjację różnic. Owa negocjacja powoduje odejście od koherencji monokonfesyjności sacrum w przestrzeni edukacyjnej ku jego dyferencjacji. Z drugiej strony, funkcjonowanie mariawitów w przestrzeni edukacyjnej powoduje różnicowanie wewnątrzkonfesyjnego dyskursu tożsamościowego oraz - co istotne - dyskursu na temat tej mniejszości. Innymi słowy, konieczność wejścia mariawitów, poprzez edukację, w sferę publiczną spowodowało możliwość zaistnienia wewnątrzmariawickiej dyskusji dotyczącej tożsamości wyznania. W tym względzie nie można pominąć także dyskursu akademickiego dotyczącego tej mniejszości, aczkolwiek bez jej udziału. Od 1990 roku dyskurs ten przechodzi od koherencji refleksji teologicznej ku dyferencjacji przejawiającej się w podejmowaniu badań interdyscyplinarnych. Wychowanie do ekumenizmu zatem to wychowanie do świadomego i odpowiedzialnego uczestnictwa w sferze publicznej oraz etyczności w prowadzeniu badań naukowych ${ }^{14}$. Dotyczy to zarówno podmiotów kreujących debatę, jak i tych, które w niej uczestniczą. Innymi słowy, także mniejszość mariawicka powinna sprostać uczestnictwu w sferze publicznej i dyskursie akademickim. Wychowanie do ekumenizmu to również wychowanie do funkcjonowania w świecie pluralistycznym.

${ }^{14}$ Zob. opracowany przez J. Mamesa Kodeks etyczny pracownika nauki opublikowany w 1993 r. w periodyku „Nauka Polska” (1993) nr 3 i kodeks Dobre obyczaje w nauce. Zbiór zasad i wytycznych, Warszawa 1994, oraz późniejszy Kodeks etyki pracownika naukowego, Warszawa 2012. 
Mariawici stanowią z perspektywy pedagogicznej osobliwą mniejszość wyznaniową. Pomimo iż ten Kościół prowadził w przeszłości szeroką działalność oświatową, informacje na ten temat pojawiają się zasadniczo tylko w mariawickich publikacjach, a w niewielkim stopniu kwestia ta jest traktowana jako interesujący przedmiot badań konfesjoznawczych, socjologicznych czy etnologicznych. Zainteresowanie pedagogów tym zagadnieniem dotychczas było znikome, chociaż istotne wydaje się postawienie pytania o przeszłość działalności oświatowej Kościoła Starokatolickiego Mariawitów i jej implikacje ideologiczne, ale także o współczesne konteksty egzystowania tej wspólnoty w przestrzeni edukacyjnej ${ }^{15}$.

Przemiany ustrojowe, jakie dokonały się w Polsce po 1989 roku, pozwoliły na emancypację sfery religijnej i przeniesienie jej z przestrzeni prywatnej ku przestrzeni publicznej, a w tym politycznej. Nie chodziło tu tylko i wyłącznie o powstanie nieskrępowanej możliwości publicznego manifestowania swoich przekonań religijnych, ale nade wszystko uruchomienie poprzez ową możliwość mechanizmów sakralizacji tego, co publiczne. Sacrum w przestrzeni publicznej stało się nie tyle jego składową czy pewnego rodzaju elementem strukturalnym, ile raczej wartością determinującą postrzeganie rzeczywistości społecznej. Nastąpiło zatem przesunięcie akcentu z doświadczania religii w wymiarze jednostkowym na doświadczanie jej w wymiarze makrospołecznym. W konsekwencji argumentacja religijna, determinująca myślenie i działanie jednostki, została rozszerzona na religijne determinowanie dyskursu publicz-

${ }^{15}$ Trudno mówić o jakimś kontinuum w odniesieniu do współczesnej działalności oświatowej mariawitów (z racji na upaństwowienie szkolnictwa mariawickiego po 1945 roku), a w związku z tym porównywanie funkcjonowania mariawitów w przestrzeni edukacyjnej w latach 1893-1959 oraz 1959-1989 i w okresie od przemian ustrojowych w Polsce do czasu obecnego jest niezwykle trudne. Wynika to nie tylko z odmiennego zasięgu oddziaływań mariawickich ośrodków edukacyjnych czy form owej działalności, ale przede wszystkim z odmiennego położenia prawnego Kościoła. 
nego ${ }^{16}$. Jedną z konsekwencji tego przeniesienia była instrukcja Ministra Edukacji Narodowej z dnia 3 sierpnia 1990 roku o powrocie nauczania religii, a uściślając: religii rzymskokatolickiej, do szkół publicznych. Mniejszości wyznaniowe, w tym Kościół Starokatolicki Mariawitów, zostały postawione przez rozporządzenie przed faktem dokonanym. Nikt bowiem nie konsultował tej kwestii z przedstawicielami Kościołów zrzeszonych w Polskiej Radzie Ekumenicznej czy z innymi Kościołami i wspólnotami religijnymi ${ }^{17}$. Dopiero po zaskarżeniu do Trybunału Konstytucyjnego decyzji MEN wydano odpowiednie rozporządzenie (z dnia 14 kwietnia 1992 roku), które regulowało status nauczania religii nierzymskokatolickich związków wyznaniowych. Z władzami Kościoła mariawitów konsultowano natomiast treść ustawy (z dnia 20 lutego 1997 roku) o stosunku Rzeczypospolitej do tegoż wyznania. Znalazły się tam zapisy odnoszące się do prowadzenia przez Kościół instytucji oświatowych, w tym szkolnictwa wyższego, oraz gwarancji dotyczących prowadzenie katechezy wyznaniowej w szkołach ${ }^{18}$. Wychowanie do ekumenizmu to także troska o wizerunek publiczny i rozwój własnego Kościoła w przestrzeni publicznej.

Zgodnie z ustawą z 1997 roku poręczono Kościołowi prawo nadawania tytułu zawodowego licencjata teologii mariawickiej oraz prowadzenia Wyższego Seminarium Duchownego w Płocku. Poręczono także kształcenie studentów w ramach sekcji teologii starokatolickiej w Chrześcijańskiej Akademii Teologicznej w Warszawie. Oznacza to, że mariawiccy absolwenci WSD oraz ChAT-u mogą legitymować się zawodowym lub wyższym wy-

${ }^{16} \mathrm{Na}$ marginesie warto odnotować, że jednym z efektów tego procesu było powstawanie m.in. partii politycznych odwołujących się wprost do autorytetu Kościoła rzymskokatolickiego (czy w ogóle doktryny chrześcijańskiej), które to przejawiały silny lobbing w parlamencie na rzecz dominacji dyskursu rzymskokatolickiego w przestrzeni edukacyjnej.

${ }^{17}$ B. Milerski, Religia a szkoła. Status edukacji religijnej w szkole w ujęciu ewangelickim, Warszawa 1998, s. 68-91.

${ }^{18}$ M. Winniczuk-Kossakowska, Ustawy III Rzeczypospolitej o stosunku państwa do Kościołów chrześcijańskich, Warszawa 2004, s. 484-489. 
kształceniem teologicznym, a także prowadzić lekcje religii mariawickiej w szkołach publicznych. Obecnie odnośnie do duchowieństwa Kościół przyjmuje zasadę kształcenia kadr w ChAT, zaś WSD pełni raczej rolę placówki formacyjnej aniżeli kształcącej. Również kształcenie świeckich katechetów odbywa się w ramach sekcji starokatolickiej na warszawskiej uczelni ekumenicznej ${ }^{19}$ oraz na kursach katechetycznych, organizowanych przez mariawickie seminarium duchowne w Płocku. Wychowanie do ekumenizmu realizowane jest zatem poprzez odpowiednie przygotowanie kadr duchownych i katechetycznych, w którym znamienną rolę odgrywają ośrodki naukowe. Szczególnie dotyczy to Chrześcijańskiej Akademii Teologicznej, w której prowadzone są badania naukowe nad doktryną różnych wyznań, historią relacji interkonfesyjnych oraz studia nad dokumentami dialogów ekumenicznych. Ponadto prowadzona jest działalność wydawnicza ${ }^{20}$.

Odrębną kwestią pozostaje dostrzeżenie w programie studiów teologii starokatolickiej zróżnicowania konfesyjnego w obrębie polskiego starokatolicyzmu, ze szczególnym uwzględnieniem mariawityzmu. Wydaje się bowiem, że zróżnicowanie jurysdykcyjne, jak i doktrynalne polskich Kościołów starokatolickich powinno implikować zróżnicowanie przynajmniej w obrębie niektórych nauczanych przedmiotów. Treści programowe nie ograniczają się tylko do podania dość ogólnych informacji, fundamentalnych dla wszystkich Kościołów Unii Utrechckiej, ale dotykają także problematyki historii i teologii zarówno płockiego, jak i felicjanowskiego nurtu w mariawityzmie. Program zajęć przeznaczonych dla studentów teologii starokatolickiej jest zatem tak skonstruowany, że treści przekazywane na poszczególnych przedmiotach są różnicowane ze względu na odmienność konfesji, których dotyczą. Dla przykładu: przedmiot katechetyka w bloku kształcenia pedagogicznego nie został roz-

${ }^{19}$ E. Gajda, Wybór źródeł do nauki prawa wyznaniowego, Toruń 2004, s. 282-283.

${ }^{20}$ Zob. ks. P. Kantyka, Rola placówek naukowych w dialogu ekumenicznym, [w:] Rola placówek naukowych $w$ dialogu ekumenicznym, red. M. Poniewierska (Biblioteka Ekumenii i Dialogu, 25), Kraków 2004, s. 31-33. 
dzielony według kryterium konfesyjnego, jednak sylabus tego kursu uwzględnia zarówno polskokatolicką, jak i mariawicką specyfikę nauczania religii w szkołach i punktach katechetycznych. Wprawdzie nie ma szerszej literatury traktującej o katechetyce Kościoła Starokatolickiego Mariawitów oraz innych Kościołów starokatolickich, jednak studenci korzystają z praktyki i informacji przekazywanych przez prowadzących zajęcia. Wykładowcy bazują zatem na doświadczeniu własnej wspólnoty wyznaniowej oraz prowadzą badania dotyczące wymiaru teoretycznego i prakseologicznego katechetyki innych Kościołów, w tym Kościoła Starokatolickiego Mariawitów. Jest to pytanie nie tyle o konstruowanie dyskusji nad mariawityzmem w ogóle, ile o tożsamość katechetyki mariawickiej jako subdyscypliny pedagogicznej i teologicznej. Wychowanie do ekumenizmu przejawia się w poznaniu doktryny własnego Kościoła i specyfiki teologii Kościołów siostrzanych.

W tym miejscu pojawia się refleksja dotycząca wychowania do ekumenizmu za pomocą medium, jakim jest słowo mówione. W czasopiśmie „Mariawita” regularnie przedstawiane są wiernym informacje z życia innych Kościołów w Polsce oraz poza jej granicami. Skrzętnie odnotowano np. fakt śmierci kardynała Józefa Glempa, ważne wydarzenia z życia Polskiego Autokefalicznego Kościoła Prawosławnego, obrady Światowej Rady Kościołów czy Konferencji Kościołów Europejskich. Redakcja tego czasopisma zamieszcza również np. pisma gratulacyjne od władz Kościołów zrzeszonych w PRE i Kościoła Rzymskokatolickiego. Umieszczane są również wzmianki dotyczące udziału władz Kościoła, kapłanów oraz wiernych w nabożeństwach ekumenicznych, takich jak organizowane w Tygodniu Modlitw o Jedność Chrześcijan czy marcowy Dzień Modlitw. Również edukacja ekumeniczna wpisana jest w program nauczania katechezy zarówno na szczeblu podstawowym, jak i gimnazjalnym ${ }^{21}$. Podobne treści realizowane są na trzecim etapie edukacyjnym.

${ }^{21}$ Zob. np. Program Nauczania Religii Mariawickiej w Szkole Podstawowej i Gimnazjum, Płock 2001, s. 35. 
Cechą charakterystyczną publikacji naukowych traktujących o mariawityzmie jest ujmowanie tego wyznania jako swoistego fenomenu. Świadczą o tym badania religioznawcze, historyczne, socjologiczne, pedagogiczne czy wreszcie teologiczne. Niemniej jednak interpretacja interesującej badacza przestrzeni zostaje ograniczona ramami teologii Kościoła, z którą badacz się utożsamia, bądź do której się odwołuje ${ }^{22}$. Zjawisko to nie odnosi się do dyskursu na temat doktryny mariawickiej, w którym konfesja badacza (lub ramy teologii, którą badacz przyjmuje) determinuje interpretację penetrowanej rzeczywistości ${ }^{23}$. Z drugiej jednak strony daje się coraz wyraźniej zauważyć dążenie do obiektywizmu historycznego, co jest charakterystyczne dla większości współczesnych nam prac monograficznych, w których mariawityzm jest albo przedmiotem badań, albo też jednym z omawianych problemów.

Z faktu uczynienia konfesyjnym współczesnego dyskursu dotyczącego mariawityzmu wynikają istotne implikacje dla funkcjonowania tegoż wyznania w przestrzeni edukacyjnej w ogóle, a dla wychowania do ekumenizmu w szczególności. Nie chodzi o dostrzeganie związania z Kościołem (a nie ze zgromadzeniami zakonnymi czy osobami świeckimi) wszelkich inicjatyw edukacyjnych, ale przede wszystkim o konstruowanie dyskursu naukowego wokół tej mniejszości. Owo konstruowanie ma miejsce przede wszystkim w dziedzinie oświaty akademickiej i - co osobliwe - toczy się jeśli nie poza nią, to na pewno obok tej mniejszości. Z jednej bowiem strony wzrasta zainteresowanie zarówno historią, jak i doktryną (choć raczej postrzeganą przez pryzmat historii) mariawityzmu, z drugiej zaś następuje dyfe-

${ }^{22}$ Paradoksem wydaje się zatem, że prace na temat historii mariawityzmu charakteryzują się zabarwieniem teologicznym, gdy tymczasem po II wojnie światowej nie powstała w Polsce żadna praca analizująca kompleksowo doktrynę Kościoła Starokatolickiego Mariawitów.

${ }^{23} \mathrm{~Np}$. ks. Henryk Seweryniak w swojej książce Święte Oficjum a mariawici (Płock 2014) wychodzi z apriorycznego założenia o fałszywości objawień św. Marii Franciszki Kozłowskiej. 
rencjacja dyskursu dotyczącego tej wspólnoty wyznaniowej. Nastąpiła emancypacja dyskursu przejawiająca się w poliwalencji perspektyw badawczych: teologicznej, socjologicznej, religioznawczej, pedagogicznej itp. ${ }^{24}$.

Charakterystyczne jest to, iż Kościół Starokatolicki Mariawitów miał dotychczas znikomy wpływ na kształt dyskursu na tematmariawityzmu. Dość długo utrzymywała się wewnętrzna koherencja dyskursu (teologicznego) przejawiająca się w konstruowaniu zunifikowanej interpretacji własnej doktryny i historii. Świadczy o tym nie tylko wydawanie jednego organu prasowego Kościoła, czasopisma „Mariawita”, ale także publikowanie przez autorów mariawickich prac o mariawityzmie przede wszystkim w oficjalnym wydawnictwie Kościoła ${ }^{25}$. W konsekwencji treści zawarte zarówno w „Mariawicie”, jak i w tych publikacjach z założenia musiały prezentować oficjalną wykładnię doktryny i historii, przyjętą przez Kościół.

Wydaje się, że po 1989 roku otwarcie się Kościoła na zewnątrz było konsekwencją realnego zaistnienia tego wyznania w przestrzeni publicznej, do której należy także przestrzeń szkoły. Na-

${ }^{24}$ Aby zobrazować ową polikontekstualność dyskursu, pozwolę sobie przytoczyć tematy kilku prac magisterskich pisanych o mariawityzmie: M. Wieczorkiewicz, Stosunek społeczeństwa polskiego do Kościoła mariawitów w okresie międzywojennym (1918-1939) (promotor: prof. dr hab. R. Bender, KUL 1990); A. Żarnowska, Obraz mariawityzmu w tekstach objawień założycielki i artykułach polemicznych (lata 1906-1908) (Instytut Historyczny UW, 2002), R. Zaniecki, Obraz Kościoła Starokatolickiego Mariawitów w świetle czasopisma „Mariawita” w latach 1960-1980 (promotor: ks. prof. dr hab. W. Nowak, Wydział Teologiczny UW-M, 2000), T. Kos, Działalność społeczno-kulturalna i gospodarcza Kościoła i organizacji mariawickich w opinii mariawitów (promotor: prof. dr hab. K. Heffner, UŁ, 2000), M. Ciesielska, Stosunki Starokatolickiego Kościoła Mariawitów wobec Kościoła Rzymskokatolickiego w latach 1904-1939 (promotor: prof. dr hab. Z. Waszkiewicz, Instytut Historii i Archiwistyki UMK, 2004).

${ }^{25}$ Wydawnictwo Kościoła Starokatolickiego Mariawitów po 1989 roku wydało zaledwie kilka publikacji: Teologia Miłosierdzia Bożego, red. P. Jaworska, Płock 2003; S. Gołębiowski, Św. Maria Franciszka Kozłowska. Życie i dzieło, Płock 2002, M. F. Kozłowska, Dzieło wielkiego miłosierdzia, dz. cyt.; ks. S. M. R. Żaglewski, Świątynia Miłosierdzia i Miłości w Płocku - święte miejsce mariawitów, Płock 2014. 
uka religii w szkole implikowała wyznaniowe ujawnienie się wyznawców, co pociągało za sobą konieczność nie tylko katechizowania współwyznawców, ale też edukacji religijnej skierowanej do środowiska lokalnego. Brak publikacji książkowych stanowił istotną barierę w tej kwestii, stąd wydaje się, że ukazanie się drukiem broszury Władysława S. Gintera było pierwszym zwiastunem otwarcia się społeczności płockich mariawitów na dyskurs publiczny ${ }^{26}$. Trudno oczywiście stawiać jednoznaczne tezy, ale warto pokusić się o pytanie (na razie retoryczne), czy wejście katechezy mariawickiej do szkół nie wpłynęło w jakimś stopniu na powołanie bilateralnej komisji teologicznej do dialogu pomiędzy Kościołem Rzymskokatolickim a Kościołem Starokatolickim Mariawitów (1997) ${ }^{27}$. Również proces przygotowania i uchwalenie przez parlament odrębnej ustawy o stosunku Rzeczypospolitej do Kościoła Starokatolickiego Mariawitów stawało się dodatkowym związkiem mariawitów z przestrzenią publiczną i jednocześnie kolejnym impulsem do bliższego przyjrzenia się tej mniejszości wyznaniowej: polikontekstualnej refleksji naukowej oraz autorefleksji tożsamościowej mariawitów. Wychowanie do ekumenizmu to tworzenie wspólnoty inkluzyjnej.

Wewnątrz samej wspólnoty Kościoła Starokatolickiego Mariawitów nastąpiła pewnego rodzaju krótka dyferencjacja dyskursu, przejawiająca się w powstaniu dwóch czasopism: „Naszego Głosu", tworzonego przez młodzież parafii warszawskiej, oraz „Pracy nad Sobą”, wydawanej w Krakowie przez ekumeniczne Zgromadzenie Mariawitów ${ }^{28}$. Obydwa czasopisma zaczę-

${ }^{26}$ S. W. Ginter, Informator o Kościele Starokatolickim Mariawitów, Płock 1986.

${ }^{27}$ Owocem prac komisji są dwie publikacje: Dwustronna refleksja na temat podstawowych pism matki Marii Franciszki Kozłowskiej dotyczacych Dzieła Wielkiego Miłosierdzia, Łódź-Włocławek 2006, oraz Ze źródeł kwestii mariawickiej. Nieznane dokumenty z lat 1903-1906, Płock 2011.

${ }^{28}$ Zgromadzenie Mariawitów jest najmłodszą - obok Zgromadzenia Kapłanów Mariawitów i Zgromadzenia Sióstr Mariawitek - rodziną zakonną w Kościele Starokatolickim Mariawitów. Funkcjonuje jako prywatne stowarzyszenie pobożne. Jego członkowie należą do kilku Kościołów chrześcijańskich. Siedzibą władz zgromadzenia jest Stoczek k. Lublina. 
ły pełnić rolę przestrzeni dyskusji nad problemami, takimi jak tożsamość wyznaniowa, historia wspólnoty czy doktryna. Jednak w swojej formie charakteryzowały się odmiennością w stosunku do „Mariawity”, pozwalając swoim autorom na dużą swobodę dociekań teologicznych, filozoficznych czy historycznych. Po zakończeniu wydawania „Naszego Głosu” w środowisku warszawskim taką rolę przejęło forum internetowe witryny para$\mathrm{fii}^{29}$. Innym przejawem dyferencjacji dyskursu tożsamościowego wewnątrz płockiego mariawityzmu była organizacja czterech ogólnopolskich konferencji teologicznych o charakterze ekumenicznym. Trzy pierwsze poświęcone były idei Miłosierdzia Bożego ${ }^{30}$, ostatnia natomiast stuleciu samodzielności wyznaniowej Kościoła Starokatolickiego Mariawitów.

Wart odnotowania jest fakt, że powyższe inicjatywy Kościoła były jedynymi konferencjami mariawitologicznymi, to znaczy w całości poświęconymi problematyce mariawickiej. Wydaje się, że właśnie ekumeniczny wymiar tych wydarzeń jest istotny nie tylko dla środowiska naukowego, ale przede wszystkim dla samych mariawitów. Wynika to z możliwości wpływu na kształt konstruowania wspomnianego dyskursu, a także na wartość spotkania na pograniczu dyskursu politeologii oraz teologii i nauki. Za Januszem Tarnowskim należałoby zatem zwrócić uwagę na następującą kwestię: „nadal wolność stanowi niezbędną płaszczyznę procesu pedagogicznego, a także nie ma wychowania bez autentycznego dialogu, który powinien prowadzić do egzystencjalnych spotkań uwieńczonych zaangażowaniem"31. Dyferencjacja wewnętrzna dyskursu tożsamościowego i ta dziejąca się nad tym dyskursem (konstruująca dyskurs już nie intra-mariawicki, a nad mariawityzmem), prowadzi do odsłonięcia nowych płaszczyzn interpretacji. Odsłonięcie

${ }^{29}$ www.forum-mariawita.hostingpro.pl. Obecnie forum zawiesiło działalność.

${ }^{30}$ Ich pokłosiem jest praca Teologia Miłosierdzia Bożego..., dz. cyt.

${ }^{31}$ J. Tarnowski, Podzwonne dla pedagogiki egzystencjalistów?, [w:] Idee pedagogiki filozoficznej, red. S. Sztobryn, B. Śliwerski, Łódź 2003, s. 90-91. 
nowych sensów (które w gruncie rzeczy są rzeczywistością istniejącą przed naszym poznaniem jako terra incognita) pozwala na (re)konstruowanie przez mariawitów tożsamości wyznaniowej oraz poprzez dialogiczne spotkanie (doświadczenie owej re-konstruowanej tożsamości) z mariawitami daje możliwość zaistnienia wolności/tolerancji religijnej. Przy odnoszeniu tego problemu do postępujących procesów globalizacji, w tym europeizacji, szczególnego znaczenia nabiera decentracja dyskursu. Idąc za myślą, że „w znaczeniu makrokulturowym decentracja jest akceptacją wielości kultur, których nie można zredukować, hierarchizować czy też ujmować w kategoriach uniwersalności" ${ }^{32}$, należałoby odnieść powyższe stwierdzenia także do dyskursu dotyczącego mariawityzmu i dyskursu wewnątrzmariawickiego. Tożsamość wyznaniowa stanowi integralny element tożsamości kulturowej, która, jak to referuje Jerzy Nikitorowicz,

łączy z kategorią wspólnoty to, co indywidualne, z tym, co społeczne, to, co rodzinne i lokalne, z tym. co globalne i uniwersalne. I co istotne - globalizacja może zaistnieć jako efekt otwarcia grup terytorialnych i mikrokulturowych i ma tym większy zasięg i zakres, im bardziej jest nasycona lokalnościąa

Dyferencjacja dyskursu nie jest więc ujmowana przeze mnie jako zagrożenie dla tożsamości wyznaniowej - w skali zarówno makrospołecznej, jak i doświadczenia jednostkowego - a rosnące zainteresowanie mariawityzmem jako fenomenem socjologiczno-kulturowo-pedagogiczno-religijnym może przyczynić się do wzmocnienia, a nie rozszczepienia owej tożsamości. Wychowanie do ekumenizmu jawi się w tej perspektywie jako umiejętność prowadzenia wewnętrznej debaty na tematy trudne, tabu-

${ }^{32}$ I. Kość, Przemiany systemu polskiej edukacji w warunkach procesu europeizacji, Szczecin 2006, s. 28.

${ }^{33}$ J. Nikitorowicz, Promocja paradygmatu wspótistnienia i dialogu kultur poprzez edukację w społeczeństwach pluralistycznych, [w:] Inspiracje i kierunki myślenia o edukacji w dobie jej reformowania, red. W. Prokopiuk, Olecko 2001, s. 149. 
izowane, a jednocześnie polemizowania i „ścierania się” na argumenty z innymi.

Kościół Starokatolicki Mariawitów, podobnie jak i inne wspólnoty mniejszościowe, nie był przygotowany na uczynienie z nauczania religii przedmiotu szkolnego. Wypracowane w rzeczywistości Polskiej Rzeczypospolitej Ludowej formy katechizacji odpowiadały ówcześnie zarówno potrzebom Kościoła, jak i wiernych, a także były dostosowane do możliwości podejmowania działań edukacyjnych przez wspólnotę mniejszościową. Wejście katechezy mariawickiej w przestrzeń szkolną implikowało stworzenie programów nauczania, systematyczne organizowanie warsztatu pracy pedagogicznej i podnoszenie kwalifikacji zawodowych nauczycieli religii, a także opracowanie podręczników.

W związku z wprowadzeniem katechezy do szkół poszczególni katecheci opracowywali w porozumieniu z władzami Kościoła autorskie programy nauczania religii, które - po ewaluacji - mogły się stać fundamentem opracowania podstaw programowych. Dotychczas opracowano podstawy programów nauczania religii w szkołach ponadgimnazjalnych ${ }^{34}$ oraz wprowadzono program dla szkół podstawowych i gimnazjalnych ${ }^{35}$. Brak nowej podstawy programowej katechezy dla szkół podstawowych oraz gimnazjów wynika z niezakończonej ewaluacji poszczególnych programów nauczania na szczeblu podstawowym oraz gimnazjalnym. Skomplikowana procedura ewaluacji programów implikowana jest katechizowaniem zarówno w szkołach (w klasach oraz w zespołach międzyklasowych), jak i w międzyszkolnych punktach katechetycznych. Oznacza to, że w praktyce prawie każda parafia mariawicka funkcjonuje w odmiennym systemie kształcenie katechetycznego ${ }^{36}$. Są tak-

${ }^{34}$ Podstawa Programowa Nauczania Religii Mariawickiej w szkołach ponadgimnazjalnych, Płock 2007 (dokument niepublikowany).

${ }^{35}$ Program Nauczania Religii Mariawickiej, dz. cyt.

${ }^{36}$ W parafii w Nowa Sobótka (rok szkolny 2014/2015), obejmującej część powiatu łęczyckiego i powiatu kutnowskiego, kształcenie katechetyczne od- 
że parafie, w których z racji zbyt małej liczby katechizowanych jeszcze do niedawna nie było możliwe zarejestrowanie punktu katechetycznego ${ }^{37}$. Kwestia ta jest także powodem braku opracowania podręcznika do religii mariawickiej, co wymusza na katechetach opracowywanie na własne potrzeby skryptów, będących kompilacją różnych podręczników do religii (najczęściej rzymskokatolickich lub ewangelickich).

Powyższy problem wydaje się być skutkiem braku interkonfesyjnej debaty nad kształtem edukacji religijnej (jako składowej wychowania religijnego) w szkołach. Zakres edukacji religijnej obejmuje zarówno elementy religioznawstwa, jak i wiedzę o wyznawanej religii oraz innych wyznaniach. Edukacja jest czymś odmiennym od wychowania religijnego i formacji religijnej, aczkolwiek - z konfesyjnego punktu widzenia - powinna być z tymi elementami integralnie powiązana. W rzeczywistości jednak wymuszenie na Kościele Starokatolickim Mariawitów (a także na innych wspólnotach mniejszościowych) dostosowania się do Kościoła większościowego spowodowało postawienie mariawitów nie tylko przed faktem dokonanym, ale także przed problemami, które, praktycznie rzecz ujmując, nie istnieją przy nauczaniu religii Kościoła rzymskokatolickiego. Tym samym idea asymilacji mariawickiej mniejszości w przestrzeni edukacyjnej poprzez wprowadzenie katechezy szkolnej spowodowała paradoksalnie powstanie nowych czynników dyskryminujących. Problem ten nie tylko powoduje napięcie w fakcie rozbicia homogenizacji społeczności szkolnej, ale też rozgry-

bywa się w trzech międzyszkolnych punktach katechetycznych, zarejestrowanych przy Szkole Podstawowej w Starej Sobótce (dla gminy Grabów, pow. łęczycki), Szkole Podstawowej w Mazewie (dla gminy Daszyna, pow. łęczycki) oraz w Zespole Szkół im. J. Grodzkiej w Łęczycy (dla młodzieży ponadgimnazjalnej z terenu powiatów łęczyckiego, zgierskiego i kutnowskiego). W parafii Kadzidłowa (wyznawcy mieszkają na terenie części powiatu łęczyckiego i w powiecie kolskim) w tym samym roku szkolnym punkt katechetyczny jest zarejestrowany przy Szkole Podstawowej w Kadzidłowej.

${ }^{37}$ Np. w placówce mariawickiej w Krakowie w roku szkolnym 2006/2007 katechezą na szczeblu ponadgimnazjalnym objęta była jedna uczennica. 
wa się na płaszczyźnie korelacji z treściami programowymi innych przedmiotów nauki szkolnej. Nie chodzi tu tylko o korelowanie katechezy mariawickiej z innymi przedmiotami, ale również o dostrzeżenie faktu, iż podstawy programowe nauczania (implikujące dobór podręczników) pozostałych przedmiotów nie zawierają treści odnoszących się do historii mariawityzmu czy w ogóle kultury mariawitów jako mniejszości wyznaniowej. Kwestia ta dotyczy nie tylko braku wzmianek o mariawityzmie w podręcznikach szkolnych (np. do historii), ale także podawania nieprawdziwych informacji na temat tej wspólnoty ${ }^{38}$. Podniesione zagadnienie $\mathrm{w}$ sposób istotny stawia pytanie o koherencję wewnętrzną szkolnego planu nauczania, wychowania i opieki. Jeśli bowiem mamy do czynienia tylko z jednostronną korelacją międzyprzedmiotową (i to tylko w treściach nauczania), zaś sprzężenie zwrotne (na linii katecheza - inne przedmioty - katecheza) nie jest możliwe, to zostaje podważona zasadność twierdzenia o spójności planu nauczania, wychowania i opieki szkoły - choć na razie na płaszczyźnie samego nauczania. Z tej racji za Kazimierzem Kossakiem-Główczewskim należałoby stwierdzić, iż

w państwie nacjonalistycznym, a w takim niewątpliwie żyjemy, wprowadzana i uprawiana edukacja jest jednoznacznym przekaźnikiem wartości jednej grupy kulturowej, która posiada dostęp do programów nauczania. Dokonywana za jej pośrednictwem przemoc, głównie (choć nie tylko) symboliczna, utrwala ideologię narodową państwa jednorodnego, ograniczając rozwój jednostkowy i społeczny, a także ekonomiczny ${ }^{39}$.

Kwestia funkcjonowania mariawitów w przestrzeni edukacyjnej dotyczy także zagadnienia jej sakralizacji. Umieszczanie

${ }^{38}$ N. Davies, Boże igrzysko, Kraków 2003, s. 705; Odpowiedź Ministra na interwencję Rady Kościoła, „Mariawita” (2004) nr 10-12.

${ }^{39}$ K. Kossak-Główczewski, Szanse edukacji regionalnej; kontestacja i wyzwolenie czy dramat edukacyjny?, [w:] Inspiracje otwarcia krytyki w edukacji, red. E. Rodziewicz, Gdańsk 1995, s. 58. Zob. J. J. Peece, Prawa mniejszości, Warszawa 2007. 
w szkołach symboli religijnych, sakralizacja świąt szkolnych czy włączanie uczestników edukacji szkolnej w kult religijny jest zjawiskiem powszechnym. W środowisku jednolitym wyznaniowo, zarówno jeśli chodzi o uczniów, jak i grono pedagogiczne diafoniczność tych dwóch przestrzeni nie powoduje większych kontestacji. Inaczej sytuacja ta wygląda w odniesieniu do wieloreligijnej społeczności szkolnej. Szkoła, poprzez obecność katechetów mariawickich (obok np. rzymskokatolickich), stała się przestrzenią, w której rodzi się szansa dialogu międzyreligijnego, ale i zagrożenie przejawiające się w protestach w sferze symboliki lub kultu religijnego.

O ile umieszczanie krzyża w salach lekcyjnych nie budzi oporu wśród mariawitów, to eksponowanie w szkołach symboliki typowo rzymskokatolickiej już tak. Jako przykład niech posłuży fakt umieszczania w niektórych szkołach portretu Jana Pawła II przy jednoczesnym braku możliwości umieszczenia w szkole, do której uczęszczają dzieci mariawickie, wizerunku św. Marii Franciszki Kozłowskiej. W tym przypadku władze szkolne niekiedy skłonne są umieszczać wspólny dla mariawitów i rzymskich katolików symbol, jakim jest krzyż. Przykład ten obrazuje ścieranie się w szkolnej rzeczywistości nie tyle dwóch dyskursów religijnych, ile raczej negocjację dominacji. Można zauważyć, że rezygnacja grupy większościowej z własnego symbolu religijnego była poświęceniem poniesionym dla niezaistnienia w szkole symbolu mariawitów. Podobna kwestia pojawiła się w jednej ze szkół podstawowych, której nadano imię Jana Pawła II. Mając na uwadze fakt, że do szkoły tej uczęszcza spora grupa dzieci mariawickich, społeczność tego wyznania interweniowała u władz. Propozycja środowiska mariawickiego dotyczyła nadania szkole patrona neutralnego religijnie. Władze gminy odrzuciły wniosek mniejszości. Należy zatem zgodzić się z Walerianem Magoniem, który jest zdania, że granice tolerancji w przestrzeni edukacyjnej są zakreślane m.in. przez struktury organizacyjne szkół, władze oświatowe oraz ich kompetencje, organizację pracy dydaktycznej oraz sposób jej realizacji, a także przez postawę samego nauczyciela. Wspomniany autor zauważa, iż 
o granicach tolerancji w procesach edukacyjnych stanowią bez wątpienia struktury organizacyjne szkół i władz oświatowych oraz uprawnienia formalne i kompetencje merytoryczne określonych osób i zespołów kierujących oświatą. Centralne sterowanie procesami edukacyjnymi - twierdzi autor - rodzi tendencje zawężania granic tolerancji ${ }^{40}$.

Chodzi tu zatem o niedostrzeganie na poziomie makrospołecznych projektów edukacyjnych problemów mikrospołecznych.

Katecheza mariawicka w szkole odbywa się tam, gdzie z formalnego punktu widzenia można zorganizować lekcje w zespołach międzyszkolnych, międzyoddziałowych czy międzyklasowych. Z powodu uczęszczania uczniów wyznania mariawickiego do różnych oddziałów czy klas zaplanowanie katechezy w siatce godzin musi być dopasowane do czasu przebywania uczniów na lekcjach. W praktyce w szkołach zasadniczo uczniowie mają zaplanowaną katechezę przed lub po swoich zajęciach lekcyjnych. Są nierzadkie przypadki, iż w związku z lekcją religii rzymskokatolickiej, zaplanowaną pomiędzy innymi zajęciami, pobyt młodzieży mariawickiej w szkole się wydłuża. Problem ten dotyczy prawie wszystkich mniejszości wyznaniowych. Nie mniej problematyczną kwestią są rekolekcje wielkopostne, podczas których uczniowie otrzymują zwolnienie z zajęć lekcyjnych na trzy kolejne $\mathrm{dni}^{41}$. Choć rozporządzenie resortu odpowiedzialnego za szkolnictwo I, II i III etapu edukacyjnego sugeruje, aby w szkołach niejednolitych wyznaniowo parafie organizujące rekolekcje dążyły do ustalenia ich w tych samych terminach, to w praktyce jest to trudne. W Kościele Starokatolickim Mariawitów rekolekcje wielkopostne trwają zasadniczo trzy kolejne dni, którymi są piątek, sobota i niedziela. Wynika z tego, że dwa dni rekolekcyjne są dniami ustawowo wolnymi od zajęć szkolnych. Inaczej wygląda to w Kościele rzymskokatolickim, gdzie

${ }^{40}$ W. Magoń, Granice tolerancji w edukacji, [w:] Tolerancja jako wartość i problem edukacyjny, red. A. M. de Tchorzewski, W. M. Wołoszyn-Spirka, Bydgoszcz 2000, s. 74.

${ }^{41}$ Rozporządzenie MEN z dn. 14 kwietnia 1992, § 10. 
rekolekcje szkolne organizowane są w dniach nauki szkolnej. $\mathrm{Na}$ uwagę zasługuje również fakt, że granice administracyjne parafii mariawickich nie pokrywają się z granicami parafii rzymskokatolickich, a tym samym nie sposób ustalić jednego terminu rekolekcji dla uczniów z całej parafii mariawickiej. Oznaczałoby to konieczność ustalenia go ze wszystkimi parafiami rzymskokatolickimi, na których terenie znajdują się szkoły uczęszczane m.in. przez dzieci mariawickie ${ }^{42}$. $Z$ kolei tak postawiona kwestia prowadzi do wniosku, iż już na szczeblu rozporządzenia ministerialnego mniejszość mariawicka zmuszona jest do podporządkowania się oddziaływaniu Kościoła większościowego. Nawet jeśli założymy hipotetyczną sytuację, że w którejś z parafii uda się dojść do konsensusu, to wykluczałby on czynne włączenie szkoły do uczestnictwa w rekolekcjach. Podział na część kultową (w kościele) oraz duszpastersko-wychowawczą (w szkole) jest traktowane przez katechetów rzymskokatolickich jako pożądany model współdziałania Kościoła i szkoły ${ }^{43}$. Wprowadzenie pluralizmu konfesyjnego poprzez żądania przez mniejszość mariawicką takich samych warunków uniemożliwiłoby - hipotetycznie - realizację powyższego modelu. Innymi słowy, rekolekcje szkolne w przestrzeni edukacyjnej podtrzymują dominację Kościoła większościowego i separatyzację dzieci i młodzieży mariawickiej. Do podobnych wniosków można dojść, przywołując chociażby przykłady mszy (rzymskokatolickich) odprawianych w szkołach z racji rozpoczęcia roku szkolnego czy też poświęcania obiektów szkolnych. Wychowanie do ekumenizmu to także umiejętność określenia tego, co sporne.

Warto w tym miejscu zatrzymać się na moment nad uwagami, jakie czyni Aleksander Nalaskowski odnośnie do wpływu

${ }^{42}$ Sugestia zawarta w rozporządzeniu wydaje się niewykonalna chociażby w odniesieniu do parafii w Warszawie, Łodzi czy Płocku. Konsensus mógłby być osiągnięty jedynie wówczas, gdyby w całej Warszawie (czy Łodzi lub Płoc$\mathrm{ku}$ ) rekolekcje organizowano we wszystkich szkołach w jednym terminie.

${ }^{43}$ R. Kolano, Etapy przygotowania rekolekcji szkolnych, [w:] Szkolne rekolekcje wielkopostne. Teoria i praktyka, red. A. Błoniak, Poznań 1999. 
demokracji na szkołę. Istotna dla autora jest kategoria odpowiedzialności, która w systemie demokratycznym spoczywa na każdym uczestniku dyskursu społecznego (zarówno aktywnym, jak i biernym). Zatem - konstatuje Nalaskowski - „wszyscy jesteśmy za wszystko odpowiedzialni, co oznacza, że nasza odpowiedzialność jest w znacznej mierze rozmyta, zdepersonalizowana, żadna" ${ }^{\prime 4}$. Wobec tej diagnozy autor stawia tezę, iż prawdziwa odpowiedzialność powinna być konstruowana w oparciu o trzy kategorie, a mianowicie tożsamość, kompetencje oraz sumienie. Ostatnia kategoria zdaniem autora jest nieobecna w szkolnym dyskursie z racji braku kształtowania sumienia wychowanków przez podmioty odpowiedzialne za edukację: „takich wysiłków jako społeczeństwo wydajemy się niemal zupełnie nie podejmować. Jest bowiem wolność sumienia", a zatem nie jest to sprawą publiczną, a prywatną $a^{45}$. Nietrudno zgodzić się z Nalaskowskim, że konstruowanie własnej tożsamości w społeczeństwie demokratycznym podlega mechanizmom adaptacji do zbiorowej tożsamości celem zachowania przez podmiot władzy/wpływów/obrazu Ja. Natomiast procedury decyzyjne opierają się w pierwszym rzędzie nie na kompetencjach, ale raczej na negocjacji i większościowej akceptacji. W takim ujęciu dialog interreligijny w szkole, a w tym wychowanie do ekumenizmu, w którym uczestniczy mniejszość mariawicka, jest konstruowany w oparciu o te trzy kategorie. Idąc dalej za tą myślą, należałoby przyznać autorowi rację, iż szkoła jest dominujaco nieskuteczna, ponieważ służy jednakowo wszystkim grupom społecznym, to znaczy stara się wypracować kompromis między społecznością dominującą wyznaniowo a wieloma grupami mniejszości religijnych. Jest także ona demokratycznie nieodpowiedzialna z racji rozmycia - depersonifikacji - decydentów, mających wpływ na kształt edukacji szkolnej w skali mikro i makro. Jednak podstawowy problem tkwi w sumieniu, które zostało wypchnięte

\footnotetext{
${ }^{44}$ A. Nalaskowski, Widnokręgi edukacji, Kraków 2002, s. 176.

${ }^{45}$ A. Nalaskowski, Widnokręgi edukacji, dz. cyt., s. 177.
} 
z planu wychowawczego szkoły polskiej (wyjątkiem będzie tylko katecheza i etyka).

Warto zwrócić uwagę na jeszcze jeden aspekt funkcjonowania mariawitów i innych mniejszości wyznaniowych w sferze edukacyjnej. Oto Barbara Grabowska do głównych zadań szkoły w środowisku zróżnicowanym kulturowo zalicza m.in. „wprowadzanie w pluralizm kulturowy, wyznaniowy i przygotowanie uczniów do jego pełnej akceptacji" ${ }^{46}$. Katechizacja jako jeden ze swych celów stawia także formowanie tożsamości wyznaniowej przy jednoczesnym kształtowaniu postaw tolerancji wobec wyznawców innej konfesji. Chodzi więc o uniknięcie postaw skrajnych, jakimi są fanatyzm czy synkretyzm religijny. Nie można przejść obojętnie obok tego problemu, ponieważ w dobie współczesnego pluralizmu religijnego obydwa te zjawiska są czynnikami destabilizującymi dialog interreligijny, a także stanowią istotne zagrożenie dla tożsamości wyznaniowej katechizowanych. Zadanie katechety-pedagoga w środowisku szkolnym nie sprowadza się zatem do pracy dydaktyczno-wychowawczej tylko na lekcjach religii, ale także poza nimi. Istotą tej działalności jest tworzenie sytuacji sprzyjających dialogowi międzyreligijnemu w przestrzeni edukacyjnej przy jednoczesnym wspomaganiu konstruowania/odkrywania tożsamości wyznaniowej przez katechizowanych. Ale nie tylko to: katecheta mariawita w społeczności szkolnej jako członek rady pedagogicznej staje się translatorem mariawickiej kultury religijnej. Zetknięcie się grona pedagogicznego z nauczycielem mariawitą daje możliwość poznania odmienności wyznaniowej i zaistnienia dialogu, który będzie kontynuowany w klasie szkolnej. Godna przytoczenia jest uwaga Grażyny Piechoty, iż

znajomość zasad komunikacji międzykulturowej to stosunkowo nowe kompetencje, które niegdyś dotyczyły wąskich grup osób mających kontakt z innymi kulturami, natomiast dziś stają się kompetencjami koniecz-

${ }^{46}$ B. Grabowska, Szkoła w środowisku zróżnicowanym kulturowo, [w:] Szkoła na pograniczach, red. T. Lewowicki, A. Szczurek-Boruta, Katowice 2000, s. 70. 
nymi niemal dla wszystkich. Zmieniająca się kultura społeczna, nowe wymagania dla efektywnego uczestniczenia $\mathrm{w}$ życiu społecznym czy obywatelskim to tylko jedno z oczekiwań stawianych przed szkołą jako organizacją odpowiadającą za kształtowanie kompetencji społecznych uczniów ${ }^{47}$.

Badania przeprowadzone na Śląsku Cieszyńskim, a opublikowane w 1998 roku dają nam wiedzę o tym, iż

szkoła - zdaniem badanych [nauczycieli - przyp. T. D. M.] - powinna zapoznawać uczniów ze wszystkimi ideologiami i światopoglądami (62\%). Prawie jedna trzecia nauczycieli (27\%) proponuje, aby zawęzić ofertę do wybranych idei. Nieliczni (6\% - tylko ze szkół podstawowych) proponują ograniczenie się tylko do własnej religii, co spowodowałoby konieczność dokonywania podziału uczniów według wyznania ${ }^{48}$.

Wielokulturowość tym różni się od myślenia liberalistyczno-indywidualnego, że wnosi jakości związane z kategorią wspólnotowości i - jak podkreśla Paweł Boski - prowadzi do odmiennych konsekwencji. Liberalizm i indywidualizm, promując prawa i wolności osobiste, postulują wycofanie się światopoglądu i obyczajów (a więc i religii) ze sfery publicznej, pozostawiając je li tylko w przestrzeni prywatnego doświadczenia jednostki. Inaczej rzecz wygląda w odniesieniu do wielokulturowości, w tym do edukacji regionalnej. Znamienna jest w tym kontekście rola nauczyciela regionalisty, który

powinien być świadomy tego, że nie jest zarządcą jedynie prawomocnej monokultury i ma realizować jej administracyjną aksjologię. Winien być krytykiem kultury, próbować zmieniać i modyfikować, istotą jego pracy jest bowiem wypracowanie działań edukacyjnych przygotowujących

${ }^{47}$ G. Piechota, Edukacja komunikowania międzykulturowego - rola szkoły wobec wyzwań współczesności, [w:] Komunikacja społeczna w i dla multikulturowości, red. W. J. Maliszewski, M. Korczyński, K. Czerwiński, Toruń 2012, s. 68.

${ }^{48}$ B. Grabowska, Szkoła w środowisku zróżnicowanym..., dz. cyt., s. 76. 
wszystkich, niezależnie od pochodzenia i kultury, jaką reprezentują, do życia i współdziałania w świecie, w którym chcemy kształtować i zachować kulturę pokoju, odrzucając kolonizowanie świadomości mniejszości przez dominującą większość ${ }^{49}$.

Prezentowana w niniejszym tekście analiza kontekstów wychowania do ekumenizmu dla i w społeczności mariawickiej, która niewątpliwie jest elementem wielokulturowej mozaiki polskiego społeczeństwa, może prowadzić do wniosku o istnieniu dwubiegunowego napięcia. Z punktu widzenia procesu uczenia się - nauczania dyskurs dotyczący mariawityzmu emancypuje się z teologizacji poprzez historyczną obiektywność ku polikontekstualności. Jednak sam proces emancypacji nie powoduje aż takiego napięcia, jak uczestnictwo religii (katechezy/teologii) mariawickiej w zinstytucjonalizowanych formach kształcenia publicznego. Napięcie to jest obecne także na płaszczyźnie emancypacji symboli w przestrzeni edukacyjnej. Oczywiście przytoczone przeze mnie przykłady czy dobór literatury, w oparciu o którą dokonałem analizy, determinowane były chęcią ukazania owych napięć w konstruowanym dyskursie. Tez przeze mnie postawionych nie uważam za ostateczne, ale raczej za punkt wyjścia debaty nad miejscem wychowania do ekumenizmu w mniejszości mariawickiej, nad tą mniejszością i dla tej mniejszości oraz jego blasków i cieni w przestrzeni edukacyjnej. Należy jednak wyraźnie podkreślić, że w przestrzeni edukacyjnej powstały także dialogiczne wyspy kontestacji społeczności lokalnej wobec antagonizmów.

Podwaliny pod dialog ekumeniczny w Kościele rzymskokatolickim położył papież Leon XIII w encyklice Orientalium dignitas z 1894 roku $^{50}$. Ekumenizm np. w Kościołach tradycji protestanckiej był już wówczas rozwinięty na szeroką skalę. Również i mariawici od początku istnienia niezależnego od Rzymu

${ }^{49} \mathrm{~J}$. Nikitorowicz, Edukacja regionalna na pograniczu, [w:] Edukacja regionalna, red. A. W. Brzezińska, A. Hulewska, J. Słomska, Warszawa 2006, s. 107.

${ }^{50}$ P. Jaskóła, Podstawy ekumenizmu, Opole 2010, s. 31. 
Kościoła zaangażowali się żywo w dialog ekumeniczny. Dialog z Kościołami: Unii Utrechckiej (uwieńczony w 1909 roku sakrą o. M. Michała Kowalskiego), prawosławnymi i rzymskokatolickim, współzałożycielstwo Polskiej Rady Ekumenicznej ukazują zakres funkcjonowania społeczności mariawickiej w przestrzeni ekumenicznej. Nadanie duchownemu mariawickiemu ks. M. Grzegorzowi Dróżdżowi Orderu Uśmiechu ${ }^{51}$, organizowanie przez Kościół Starokatolicki Mariawitów inicjatyw oświatowo-charytatywnych czy fakt kierowania niepubliczną szkołą podstawową przez innego kapłana - ks. M. Gabriela Grabarczy$\mathrm{ka}$ - ukazują funkcjonowanie tego wyznania w konstruowaniu dyskursu na płaszczyźnie lokalnej. Moim zdaniem, modelowa wręcz współpraca społeczności mariawickiej z innymi Kościołami zrzeszonymi w Polskiej Radzie Ekumenicznej oraz podejmowanie wspólnych z Kościołem rzymskokatolickim inicjatyw ekumenicznych to przejawy pozytywnego i oczekiwanego zarazem efektu wychowania do ekumenizmu. Szczególnie dotyczy to tej drugiej wspólnoty, z której mariawici zostali w 1906 roku wyłączeni. Można sądzić, iż otwarcie się Kościoła rzymskokatolickiego po Vaticanum II na ruch ekumeniczny stworzyło podwaliny dla budowania poprawnych relacji również z Kościołem Starokatolickim Mariawitów. Dowodem tego jest powołanie i praca komisji do dialogu pomiędzy rzymskimi katolikami a mariawitami. Również obecność biskupów i innych duchownych rzymskokatolickich w kościołach mariawickich z okazji Tygodnia Modlitw o Jedność Chrześcijan budzi nadzieję na budowanie atmosfery serdeczności i braterskiej współpracy. Tego wszystkiego nie byłoby bez Soboru Watykańskiego II.

Błędem jest mniemać, iż blaski wychowania do ekumenizmu przejawiają się w rezygnacji z własnej tożsamości wyznaniowej. Wręcz przeciwnie - podstawą wychowania do ekumenizmu jest samoświadomość własnego zakorzenienia konfesyjnego i „święta duma” z przynależności do swojego Kościoła. Jednakże

${ }^{51}$ A. Boczkowska, Słoneczny Jubileusz. 35-lecie Orderu Uśmiechu, „Mariawita” (2003) nr 4-6, s. 20-21. 
niewątpliwym cieniem wychowania do ekumenizmu jest mniemanie o wyższości własnej osoby nad innymi z racji przynależności do takiego, a nie innego Kościoła. Fanatyzm, szowinizm, egoizm czy narcyzm religijny stoją w jaskrawej sprzeczności z przykazaniem miłości Boga i bliźniego:

racjonalny dialog religijny musi zawierać zdecydowane świadectwo wiary, ale jednocześnie nie może być ono jednostronne. Wszyscy uczestnicy dialogu powinni być przekonani o swojej wyjątkowości z jednoczesną otwartością na inne świadectwa; takie podejście stymuluje nie tylko rozwój w postrzeganiu Boga, ale i całej przeżywanej rzeczywistości ${ }^{52}$.

${ }^{52}$ M. Patalon, Pedagogika ekumenizmu, Gdańsk 2007, s. 176. 